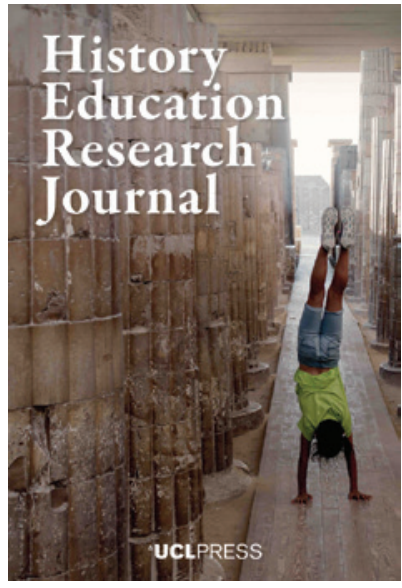

${ }^{\Perp}$ UCLPRESS

HISTORY EDUCATION RESEARCH JOURNAL

ISSN 2631-9713 (Online)

Journal homepage:

https://www.uclpress.co.uk/pages/history-educationresearch-journal

\title{
What is the purpose of studying history? Developing students' perspectives on the purposes and value of history education
}

\section{Dan Nuttall(iD}

\section{How to cite this article}

Nuttall, D. (2021) 'What is the purpose of studying history? Developing students' perspectives on the purposes and value of history education'. History Education Research Journal, 18 (1), 89-108. https://doi.org/10.14324/HERJ.18.1.06

Submission date: 12 June 2020

Acceptance date: 13 October 2020

Publication date: 20 April 2021

\section{Peer review}

This article has been peer-reviewed through the journal's standard double-blind peer review, where both the reviewers and authors are anonymized during review.

\section{Copyright}

(C) 2021 Nuttall. This is an open-access article distributed under the terms of the Creative Commons Attribution Licence (CC BY) 4.0 https://creativecommons.org/licenses/by/4.0/, which permits unrestricted use, distribution and reproduction in any medium, provided the original author and source are credited.

\section{Open access}

The History Education Research Journal is a peer-reviewed open-access journal. 


\title{
What is the purpose of studying history? Developing students' perspectives on the purposes and value of history education
}

\author{
Dan Nuttall* - UCL Institute of Education, UK
}

\begin{abstract}
This paper reports on an intervention study conducted with the A level students whom I teach at a sixth form college in the north-west of England. The study aimed to survey the students' perceptions of the purposes of history education, and to broaden their understanding of the debate. The study drew upon data from 82 online forum posts from 41 history A level students. It consisted of two stages: the first surveyed students' initial perceptions of the purposes of history education; the second aimed to further develop students' perceptions through the deployment of stimulus material and activities designed to broaden students' understanding of the issue. Following these activities, students' perceptions were surveyed for a second time to facilitate comparison. The study data indicate that students who have chosen to pursue their historical studies to a higher level tend to appreciate the intrinsic value of knowing history (as opposed to its extrinsic value, such as developing transferable skills or for the sake of employability). The study also indicates that students' perceptions of the purpose and value of historical study can be significantly altered by teacher intervention, although the long-term impact remains unassessed.
\end{abstract}

Keywords: students' perceptions, history education, purpose, intrinsic/extrinsic value of historical study

\section{Introduction}

As Barton and Levstik (2004: 27) have observed, there is "no "neutral" or "objective" approach to history that can guide [history curriculum] choices; they can only be guided by the goals we develop for the subject'. In England, the debate surrounding the purposes of history education began at least when, in 1900, the Education Department specified what should be taught in history lessons in English schools for the first time in its Code of Regulations for Day Schools (Cannadine et al., 2011: 23). More recently, the debate surrounding the 2013 draft publication of the History Programmes of Study for the national curriculum became public discourse (Burns, 2013; Mansell, 2013). (The National Curriculum for England, published by the Department for Education (DfE), specifies the statutory content that must be taught in all state-funded, localauthority-maintained schools in England. It was most recently revised in 2013, with implementation in 2014.) A shift away from second-order conceptual understanding and towards a chronology of Anglocentric history reignited pre-existing and surely lasting debates surrounding the purpose of history education.

Haydn and Harris (2010: 254) rightly state that 'there has been an extensive debate between the "grown-ups" about the purpose and nature of a historical education for 
young people', yet, they argue that this debate 'has been conducted largely over the heads' of the students. Haydn and Harris's comments are made in conclusion to their research into British students' perceptions of the purposes and benefits of history education. They surveyed the perceptions of 1,740 Key Stage 3 students (11-14 years old), from 12 different schools, as well as interviewing 160 of those students in focus groups. The most common pattern of responses given by the students in relation to the purpose of history education related to employment and employability. While a significant number directly referenced specific careers (such as history teacher, or museum curator) as the reason for a history education, few considered the intrinsic value of knowing history, such as its being useful in explaining the present (just 3 per cent of students) (cited in Van Straaten et al., 2016: 480).

While not supporting Van Straaten et al.'s (2016: 480) assertion that 'many students consider history largely irrelevant', and even tentatively suggesting some improvement in British students' perceptions of the purpose of history education compared to earlier studies (Schools Council, 1968; Hargreaves, 1984, cited in Haydn and Harris, 2010), Haydn and Harris results suggest that many of the arguments surrounding the purpose of history education have not reached the 'heads of those for whom the [history] curriculum was designed' (Haydn and Harris, 2010: 254), and that 'if they [the students] think history is important, they struggle to explain why' (Van Straaten et al., 2016: 480).

Haydn and Harris (2010: 246) found significant variation between history departments in percentages of students considering history to be a valuable subject (62.2 per cent to 80 per cent), and an even more striking impact on students' justifications of the importance of history. For example, responses such as history being 'useful to help avoid repeating the mistakes of the past' varied from between 2 per cent and 28.5 per cent of students (Haydn and Harris, 2010: 248). From this, they conclude that teachers should 'not make assumptions about pupils' understanding of the purposes and benefits of studying the subject that they teach', but rather 'devote some time and thought to these issues in order to maximize the motivation, engagement, and sense of purpose that their pupils accord to the subject' (Haydn and Harris, 2010: 254).

This paper reports on my attempts to heed their advice and address these issues with my own A level students, rather than merely assume that they were secure in their understanding of the purpose of history education, having chosen to continue it past the age of 16. (A levels are optional qualifications in England, usually studied by students between the ages of 16 and 18. At the age of 16, most English students choose to continue to study three subjects to A level standard, although other, more vocational, qualifications are also available. Around 7 per cent of English students opt to study history A level (based upon 2016 data; Carrol and Gill, 2018; Gill, 2019)). As such, it seemed necessary to first survey their initial perceptions. I needed to identify whether there was, or was not, a need to address my students' understanding about the purposes of history education, which I felt I had devoted insufficient time and thought to discussing and debating with them. I therefore devised an intervention that attempted to broaden students' understanding of the purposes of history education, to make them more aware of the debates that exist, to encourage them to question and refine their own views, and to be able to better articulate why it is that we study history.

\section{The purposes of history education: Literature review}

While it is neither plausible nor necessary to fully explore all arguments and debates about the purposes of history education here, some key arguments and perspectives should be outlined. 
The most obvious function of history education is to pass on knowledge of the past. One possible reason for doing so is to encourage the development of cultural literacy - having the 'traditional literate knowledge, the information, attitudes, and assumptions' (Hirsch, 1988, cited in McDaniel, 2009: 202) required to understand the conversations of our communities. Cultural literacy is also sometimes seen as a tool for identity building, and even a necessary precondition for national belonging (Anderson, 2006; Hirsch, 1988), but mastering the knowledge deemed necessary to become culturally literate does not necessarily lead to appropriating and assimilating it into a sense of identity (Wertsch, 2002). While criticizing cultural literacy as an aim of history education by equating it to 'cultural indoctrination' might go too far, the idea of prescribing a body of historical knowledge in order to develop a 'shared cultural experience' does indeed raise many questions (McDaniel, 2009: 202), especially with regard to single, national stories in diverse societies.

In contrast to history providing an 'inward-looking identification' based on 'our' national past, Barton and Levstik (2004: 64) have emphasized its importance in nurturing 'identification with the common good' (2004: 40), as a preparation for a pluralist democracy, providing students with the understanding and skills necessary to participate as citizens within democratic society.

Critical of any history education concerned with memorizing facts from some national canon (not least because of his research showing students' failure in this), Sam Wineburg (2018) focuses on the skills it encourages young people to develop. Through history education, students can develop the tools and understanding that allow them to separate truth from distortion, to cultivate reasoned scepticism, and to counter the tendency to confirm their own biases. These important benefits for the individual and for wider society render history education more vital than ever before, especially in a post-truth era of 'fake news' and unprecedented access to information/ disinformation (Wineburg, 2018; Collins and Stearns, 2020).

Furthermore, Collins and Stearns (2020) aim to challenge the perception that, in comparison to STEM (science, technology, engineering and mathematics), studying history is largely useless with regard to its use and value in the workplace, arguing that the skills and understanding gained from it (for example, handling evidence, extended writing, and assessing competing interpretations) are not only vital in navigating the modern world, but also highly desirable in the world of work.

While Wineburg (2018) and Collins and Stearns (2020) focus on the importance of transferable skills and understanding, others have highlighted the importance of developing metahistorical (second-order conceptual) understanding. Students must come to understand the structural basis of the discipline - the concepts of causation (Lee and Shemilt, 2009), change (Blow, 2011), evidence (Lee and Shemilt, 2003) and historical accounts (Lee and Shemilt, 2004) - if they are truly to understand history. Others, while recognizing the importance of second-order conceptual understanding, have emphasized the value of understanding substantive (first-order) concepts (Fordham, 2016). Concepts such as 'slavery', 'peasant', 'parliament' or 'revolution' require far more than a dictionary definition to be fully understood. History education illuminates and adds meaning to these concepts, and therefore illuminates students' understanding of the world, past and present.

In addition to learning about the past, it is also argued that we should learn from the past. Chapman highlights three different types of lessons to be taken from the past. The first are deontological lessons about how one should act, behave, think or feel from a moral or ethical point of view (Chapman, 2020: 56). While some consider such lessons not to be historical concerns, as they are not answerable 
through empirical research (Fordham, 2020), others include the 'ethical dimension' among the essential parts of history study (Seixas and Morton, 2013). The second type of lesson that Chapman (2020) identifies are conseqentialist lessons, addressing the prudential lessons from history about what to do (or not) in order to achieve or avoid a particular outcome. The third type are ontological lessons about 'the nature of humans, or some social or political reality' (Chapman, 2020: 56), either in general form about how humans behave in a particular situation (such as, for example, the Hobbesian view of human nature) or about particular socio-economic contexts tending to lead to certain behaviours (for example, economic hardship causing political extremism).

Taking lessons from the past is not without its dangers, and so there is controversy as to whether this should be an aim of history education. Barbara Tuchman (1978, cited in Blow et al., 2015: 303) refers to lessons from the past as being 'distant mirrors', whereby we inevitably view the past through the lens of our own experiences and beliefs, and therefore become ahistorical. The process of taking lessons from the past is also invariably selective, with 'disregard for "irrelevant" differences as well as tendentious highlighting of "significant" similarities' (Blow et al., 2015: 303).

Despite these concerns, there are those who advocate the importance of taking lessons from the past in order to ensure that history education remains relevant to young people. Van Straaten et al. (2017) argue for the use of past-present analogies (consequentialist lessons) and questions about enduring human issues (ontological lessons) as a way to help students connect past, present and future.

Connecting past, present and future as a possible purpose of history education has been the subject of much discussion in recent years. There have been calls for long-term developmental narratives (sometimes referred to as the longue durée) that might help students better understand the challenges that we and our planet currently face, and better consider possible futures (Shemilt, 2000; Nuttall, 2013; Guldi and Armitage, 2014). This ability to orient yourself in time, by understanding your place within a past-present-future continuum, can be described as historical consciousness (Rüsen, 2006). Whether the development of historical consciousness should be an aim of history education is a relatively new debate, and one that currently seems far from reaching any consensus.

A final purpose, often overlooked in the relevant literature, is simply its aesthetic value. The potential of the subject to move us, to inspire us, or to make us feel some sense of awe, should not be ignored.

\section{Statutory guidance on the purpose of history education}

Some elements of the debate above can be identified within the statutory guidance for history education in England. In the Department for Education's 2014 National Curriculum for England, the 'purpose of study' for history focuses on both the acquisition of knowledge and the understanding of particular givens - 'Britain's past and that of the wider world', 'the lives of others', 'their own identity', 'the challenges of their own times' - as well as the development of particular attitudes ('curiosity', 'thinking critically') and skills ('weighing evidence', 'asking perceptive questions') (DfE, 2013: 1). In its 'aims and objectives' for A level history (Ofqual, 2014: 13), the Office of Qualifications and Examinations Regulation (Ofqual; the government body responsible for qualifications and examinations in England) presents a similar picture of the government's aims for history education. A focus on aesthetic value, on understanding the contexts and diversity of others, on asking perceptive questions, on developing critical thinkers, 
on using evidence and making judgements: all these remain similar between the two documents. Yet there are some additional aims included at $A$ level that do not appear in the national curriculum. These include a focus on developing independent learning skills, as well as the ability to organize and communicate understanding. In the A level aims, there is a greater sense of history being a subject of exploration, ambiguity and reflection. There are two notable omissions from the A level aims, when compared to the national curriculum: the focus on understanding their 'own identity' has disappeared, as has the reference to understanding the present 'challenges of their time'.

\section{Context and Stage 1 methodology}

The data in this study are taken from entries to an online discussion forum that were made between December 2019 and January 2020. The 82 responses are from 41 students in two classes in a single sixth form college in the north-west of England. All participants were aged 16 or 17 , and in their first year of studying A level history.

All student participants were fully informed, in writing, of the purpose of the study, the usage of their data and its full anonymization; they were given the option to withhold or withdraw their data at any time prior to publication, and they consented by signature.

The study had two stages. The first intended to gather students' initial perceptions of the purpose of history education, both to be compared to the statutory aims outlined by the DfE and Ofqual, and as a benchmark against which to 'measure' progress following Stage 2 of the study: to what extent could I further develop their ideas and perceptions?

To achieve this aim, students were asked, without any prior warning, discussion or instruction, to write an online post of a hundred words or more answering the question, 'What is the purpose of studying history?' In an effort to reduce conformity, students were not permitted to discuss their ideas and nor could they read the posts of others until they had submitted their own response.

\section{Stage 1: Initial data and discussion}

The 41 first responses collected were categorized using the Chapman et al. (2018) coding scheme (Table 1), which was extended with custom codes to capture concepts not included there (Table 2). The results are summarized in Table 3.

Students' responses were more complex than Haydn and Harris's (2010) research suggested. This difference is possibly explained by two factors: (1) all students who participated in this study had chosen to continue their historical studies past the age of 16 , so they must have seen some benefit in doing so; and (2) the students were older than those surveyed in previous studies, and so likely to be capable of more sophisticated thinking and/or to have been exposed to different ideas.

Mapping the data against the purposes of history education as proposed by the Department for Education (DfE, 2013) reveals that some of those purposes were clearly recognized by the students (see Table 4).

It is perhaps striking that no students made any mention of their own identity, in contrast to the DfE's (2013: 1) stated purpose that students should come to 'understand ... their own identity'. There was also no consideration of the study of the past as a means to understand oneself or one's own nation. Similarly, none of the students referenced developing independent learning skills as a purpose of studying 
Table 1: Explanation and illustration of codes deployed (Chapman et al., 2018: 8)

\begin{tabular}{|c|c|c|}
\hline Code & Explanation & Illustration \\
\hline $\begin{array}{l}\text { Knowledge and } \\
\text { understanding of } \\
\text { the past }(K P)\end{array}$ & $\begin{array}{l}\text { Because it enables students } \\
\text { to acquire knowledge about } \\
\text { the past (without further } \\
\text { explanation). }\end{array}$ & $\begin{array}{l}\text { 'an interest in the past and a } \\
\text { desire to increase knowledge } \\
\text { and understanding is a } \\
\text { good thing.' }\end{array}$ \\
\hline $\begin{array}{l}\text { Understanding of } \\
\text { the present (UP) }\end{array}$ & $\begin{array}{l}\text { Because it is a source of } \\
\text { knowledge that enables } \\
\text { students to make sense of the } \\
\text { world in which they live. }\end{array}$ & $\begin{array}{l}\text { 'by helping ... students to } \\
\text { place themselves within } \\
\text { some sort of context, e.g. } \\
\text { immigration ... then we have } \\
\text { gone some way towards giving } \\
\text { our subject an important role } \\
\text { in the curriculum.' }\end{array}$ \\
\hline $\begin{array}{l}\text { National identity/ } \\
\text { pride (NI) }\end{array}$ & $\begin{array}{l}\text { As an instrument for promoting } \\
\text { national identity and/or pride } \\
\text { in national identity. (Pride is not } \\
\text { an essential component of this } \\
\text { category.) }\end{array}$ & $\begin{array}{l}\text { 'I think history in schools plays } \\
\text { an important role in educating } \\
\text { young people in what it means } \\
\text { to be British. Without wishing } \\
\text { to sound overly jingoistic, I } \\
\text { think young people should be } \\
\text { proud to be British and of this } \\
\text { country's past.' }\end{array}$ \\
\hline
\end{tabular}

Group identity (GI) As a means of establishing the 'As a way for minority groups to be empowered.'

Personal identity/ pride $(\mathrm{PI})$

Citizenship/ community cohesion (CC)

Prudential uses of history (Pru)

Understanding difference (UD) identity of particular groups and/or strengthening the confidence and/or pride of those groups. (Pride is not an essential component of this category.)

As an instrument for promoting personal identity and/or pride in personal identity. (Pride is not an essential component of this category.)

As an instrument for promoting community cohesion and commitment to democratic values.

Because it helps us to learn from the past - how to avoid repeating the same mistakes, or to understand the impact of particular kinds of action.

Because it broadens students' conceptions of what it means to be human; it enables them to look beyond their own experience and current context, and appreciate other possibilities and ways of seeing the world. 'history does ... allow pupils to develop an idea of identity through connections to multiple groups, their own country, their local history, etc.' 'If you believe school history is about developing informed, "responsible citizens who make a positive contribution to society" (DfE, 2008), then the study of history cannot be left out.'

'Through this, history can also instil morals/values by teaching the implications of certain actions. Students should be able to draw parallels between different events in history to perhaps predict the outcome of future actions.'

'It helps us have an appreciation of where others come from and why they may view things differently to yourself.' 
Table 1: (continued)

\begin{tabular}{|c|c|c|}
\hline Code & Explanation & Illustration \\
\hline $\begin{array}{l}\text { Historical } \\
\text { consciousness (HC) }\end{array}$ & $\begin{array}{l}\text { Because it enables students to } \\
\text { understand living in time. } \\
\text { The temporal dimension spans } \\
\text { past, present and future. }\end{array}$ & $\begin{array}{l}\text { 'With history we are able to } \\
\text { identify what is transient and } \\
\text { what is enduring, and where } \\
\text { we stand in the flow of time.' }\end{array}$ \\
\hline $\begin{array}{l}\text { Transferable/ } \\
\text { generic skills (TG) }\end{array}$ & $\begin{array}{l}\text { Because it helps students } \\
\text { develop useful transferable } \\
\text { and/or generic skills. }\end{array}$ & $\begin{array}{l}\text { 'the skills ... can be described } \\
\text { as nothing but beneficial } \\
\text { to a student's academic } \\
\text { career, even if they forget the } \\
\text { information.' }\end{array}$ \\
\hline $\begin{array}{l}\text { Intellectual } \\
\text { maturity (IM) }\end{array}$ & $\begin{array}{l}\text { Because it contributes to the } \\
\text { development of students' } \\
\text { intellectual and/or personal } \\
\text { maturity. }\end{array}$ & $\begin{array}{l}\text { 'It is a tremendously } \\
\text { demanding intellectual } \\
\text { endeavour that sharpens } \\
\text { the mind and builds up our } \\
\text { "intellectual muscles"'. }\end{array}$ \\
\hline $\begin{array}{l}\text { Disciplinary } \\
\text { knowledge (DK) }\end{array}$ & $\begin{array}{l}\text { Because it enables students } \\
\text { to master history-specific } \\
\text { concepts and forms of } \\
\text { thinking. }\end{array}$ & $\begin{array}{l}\text { 'Developing increased } \\
\text { awareness of the nature of } \\
\text { how evidence is used to } \\
\text { support a claim ... and other } \\
\text { metahistorical concepts and } \\
\text { processes ... are certainly } \\
\text { things that ... any successful } \\
\text { history student ... gains as a } \\
\text { by-product of studying history'. }\end{array}$ \\
\hline $\begin{array}{l}\text { Fascination/ } \\
\text { aesthetic } \\
\text { appeal (FA) }\end{array}$ & $\begin{array}{l}\text { Because of its intrinsic interest } \\
\text { and power to affect students. }\end{array}$ & $\begin{array}{l}\text { 'history should be about } \\
\text { engaging with the past with } \\
\text { excitement, and the beauty of } \\
\text { history'. }\end{array}$ \\
\hline
\end{tabular}

Table 2: Additional codes added to those developed by Chapman et al. (2018)

\begin{tabular}{ll}
\hline Code & $\begin{array}{l}\text { Explanation } \\
\text { History is valuable because... }\end{array}$ \\
\hline Appreciation of life & It promotes a sense of \\
in the present (AP) & $\begin{array}{l}\text { appreciation for the positive } \\
\text { aspects of our own lives and } \\
\text { society, when compared to the } \\
\text { lives of people in the past. }\end{array}$
\end{tabular}

Respect and reverence (RR)

It allows us to pay our respects and show our appreciation of the achievements of those who have gone before us, as well as honouring the suffering, and the sacrifices that have been made.

Employment or career opportunities (EC)
It can assist students in their ambitions to achieve a particular career goal.

\section{Illustration from a} student's response

'I think that studying things such as Nazi Germany is important as it needs to be remembered to make people realize what people went through and help us to understand how lucky we are to live the way we do.'

'There are many important figures in history who are important to know about as their legacy must carry on. They did a certain thing which greatly affected the world, and this must be taught throughout the years so their hard work is never forgotten.'

'Along with my other A levels, history ... is beneficial for my choice of career pathway.' 


\begin{tabular}{lll}
\hline \multicolumn{3}{l}{ Table 3: The incidence of the coded ideas within students' Stage 1 responses } \\
\hline Codes (italics = my additional codes) & Number of students & Percentage \\
& referencing & N=41 \\
\hline Prudential uses of history (Pru) & 28 & 68.3 \\
Understanding the present (UP) & 17 & 41.5 \\
Fascination/aesthetic appeal (FA) & 15 & 36.6 \\
Knowledge and understanding of the past (KP) & 8 & 19.5 \\
Transferable/generic skills (TG) & 7 & 17.1 \\
Understanding difference (UD) & 7 & 17.1 \\
Appreciation of life in the present (AP) & 6 & 14.6 \\
Historical consciousness (HC) & 3 & 7.3 \\
Disciplinary knowledge (DK) & 3 & 7.3 \\
Citizenship/community cohesion (CC) & 3 & 7.3 \\
Intellectual maturity (IM) & 3 & 7.3 \\
Respect and reverence (RR) & 3 & 7.3 \\
Employment or career opportunities (EC) & 2 & 4.9 \\
Personal identity/pride (PI) & 0 & 0.0 \\
National identity/pride (NI) & 0 & 0.0 \\
Group identity (GI) & 0 & 0.0 \\
\hline
\end{tabular}

Table 4: Comparing the purposes of history education stated by the DfE (2013) with students' responses

\begin{tabular}{|c|c|c|}
\hline $\begin{array}{l}\text { Purpose highlighted within the } \\
\text { National Curriculum (DfE, 2013) }\end{array}$ & $\begin{array}{l}\text { Closest purpose/s as } \\
\text { coded in Chapman } \\
\text { et al. (2018) }\end{array}$ & $\begin{array}{l}\text { Percentage of } \\
\text { students identifying } \\
\text { that purpose in their } \\
\text { response } \mathrm{N}=41\end{array}$ \\
\hline $\begin{array}{l}\text { To understand the past, but for what } \\
\text { purpose is unstated ('gain a coherent } \\
\text { knowledge and understanding of Britain's } \\
\text { past and that of the wider world') }\end{array}$ & $\begin{array}{l}\text { Knowledge and } \\
\text { understanding of the } \\
\text { past (KP) }\end{array}$ & 19.5 \\
\hline $\begin{array}{l}\text { To stimulate curiosity to learn further } \\
\text { and to ask questions ('inspire pupils' } \\
\text { curiosity' and 'ask perceptive questions') }\end{array}$ & $\begin{array}{l}\text { Fascination/aesthetic } \\
\text { appeal (FA) }\end{array}$ & 36.6 \\
\hline $\begin{array}{l}\text { To develop transferable intellectual } \\
\text { abilities ('think critically, weigh evidence' } \\
\text { and so on) }\end{array}$ & $\begin{array}{l}\text { Transferable/generic } \\
\text { skills (TG) }\end{array}$ & 17.1 \\
\hline $\begin{array}{l}\text { To understand change ('the process } \\
\text { of change') }\end{array}$ & $\begin{array}{l}\text { Disciplinary } \\
\text { knowledge (DK)* }\end{array}$ & 7.3 \\
\hline $\begin{array}{l}\text { To understand the lives of others ('the } \\
\text { complexity of people's lives ... the } \\
\text { diversity of societies and relationships } \\
\text { between different groups') }\end{array}$ & $\begin{array}{l}\text { Understanding } \\
\text { difference (UD) }\end{array}$ & 17.1 \\
\hline $\begin{array}{l}\text { To understand their own identity ('as } \\
\text { well as their own identity') }\end{array}$ & $\begin{array}{l}\text { Personal identity/ } \\
\text { pride (PI), national } \\
\text { identity/pride (NI) and } \\
\text { group identity (GI) }\end{array}$ & 0 \\
\hline $\begin{array}{l}\text { To understand the present ('the } \\
\text { challenges of their time') }\end{array}$ & $\begin{array}{l}\text { Understanding the } \\
\text { present (UP) }\end{array}$ & 41.5 \\
\hline
\end{tabular}


history, as specified in Ofqual's (2014) aims for A level history. Two (4.9 per cent) did, however, highlight the role of historical study in developing their communication skills.

Overall, most students seem to appreciate the intrinsic value of knowing history. The three most common ideas presented within the responses (Pru, UP and FA) were all concerned with the value of historical knowledge and understanding in its own right (to draw lessons from it, to understand the present world or simply due to its aesthetic appeal), as opposed to some extrinsic purpose, such as developing transferable skills or for employability purposes. This is in stark contrast to Haydn and Harris's (2010) findings, where student responses relating to employability were the most common.

Considering that 68.3 per cent of students made reference to prudential uses of history (Pru), this deserves further discussion. The prevalence of this idea was far greater than that of any other, which is particularly noteworthy as neither of the government documents discussed earlier consider the prudential uses of history as a desired aim for the subject (DfE, 2013; Ofqual, 2014).

The way students worded the idea varied somewhat, but generally there was a high degree of uniformity in response. This student response is a typical example:

I think the purpose of studying history is to look at the past in order to make the future better. We look at the mistakes of the past and learn about them and what negative consequences it had but also what people did right and what made it positive and we can apply this to everyday life in order to improve society as a whole.

None of the 68.3 per cent of students who answered to this effect successfully exemplified how or when, in practice, humans have applied lessons from the past to direct them towards a more positive future. While this does not necessarily mean that they are unable to, it seems more than possible that, rather than any deeper understanding, the high incidences of such responses reflect a common acceptance of the idea in popular culture. Variations of George Santayana's (1905: 284) statement that 'Those who cannot remember the past are condemned to repeat it' are likely to be familiar to most students.

For comparison, in Chapman et al.'s (2018: 9) study, only 20 per cent of studentteachers' posts made reference to prudential uses of history, far lower than in my study. This could reflect the more sophisticated understanding that student-teachers have of the debate surrounding the purpose of historical study, in particular the controversies and complications relating to taking lessons from the past, discussed above.

Some student posts gave reasons for studying the past that fell outside the applied coded reasons. One student identified history as a kind of comforting antidote against an alienated ('disconnected') modern world, which allowed them to experience continuity and stability of life in a very abstract sense (the 'idea that no matter what happens, some things will always be the same').

In a different anomalous response, one student wrote:

History teaches us to ask questions and see the world in grey tones rather than black and white, to be empathetic and critical of views and evidence.

It teaches us to reflect on our moral compass and questions our position to be activists for our future.

Here, while there is clear reference to transferable skills (TG) and empathy (UG), the mentioning of the moral dimension (see Seixas, 2017) singularly goes beyond the statutory guidance for British history education. 


\section{Stage 2: Intervention}

Stage 2 involved delivering a lesson (1.5 hours long) that presented the students with stimulus material and activities that aimed to broaden their understanding of the discussion surrounding the purpose of studying history, and perhaps to re-evaluate some of their pre-existing perceptions. Table 5 shows the lesson outline.

Choosing the stimulus material was not an easy task. While there has been much written about the purpose of historical study, I was limited by time, and by the varied literacy levels of the students.

As the strongest pattern of responses in Stage 1 related to prudential uses of history, it seemed logical that the first stimulus used should address this issue. For this purpose, Harari's 'History of lawns' in Homo Deus (2016: 67-74) was chosen. In this history, Harari demonstrates how lawns developed across time, and how humans came to identify them with political and economic power and status. Taking the example of the lawn was a particularly powerful one, as lawns are something that all students would be familiar with, yet it was likely that none would have ever considered their meaning or their history. Therefore they make for an excellent example of how humans tend to accept the present as absolute and inevitable,

Table 5: The sequence of activities deployed in the intervention lesson

\begin{tabular}{|c|c|c|}
\hline Activity & Resources & Purpose \\
\hline $\begin{array}{l}\text { Students read the extract from } \\
\text { Harari (2016). They answered } \\
\text { the questions on Worksheet } 1 \\
\text { individually, shared thoughts with } \\
\text { their group (of three or four), } \\
\text { and then fed back in whole-class } \\
\text { discussion. }\end{array}$ & $\begin{array}{l}\text { Resources: 'History } \\
\text { of lawns' (Harari, } \\
\text { 2016: 67-74) and } \\
\text { Worksheet } 1 \\
\text { (Figure 1). }\end{array}$ & $\begin{array}{l}\text { To encourage } \\
\text { students to think } \\
\text { more deeply about } \\
\text { the prudential uses of } \\
\text { history and historical } \\
\text { consciousness. }\end{array}$ \\
\hline $\begin{array}{l}\text { Students read the different } \\
\text { purposes of history education as } \\
\text { identified by Stearns (1998). }\end{array}$ & $\begin{array}{l}\text { Adapted version of } \\
\text { Stearns (1998). }\end{array}$ & $\begin{array}{l}\text { To introduce to } \\
\text { students a range of } \\
\text { different purposes of } \\
\text { historical study. } \\
\text { To give greater breadth } \\
\text { to their understanding. }\end{array}$ \\
\hline $\begin{array}{l}\text { Individually, students were required } \\
\text { to 'rank' the different purposes in } \\
\text { order of their importance, using } \\
\text { a 'diamond nine' layout, whereby } \\
\text { cards are placed in rows in a } \\
\text { diamond shape, with those on the } \\
\text { higher rows deemed to be the } \\
\text { most important, and those on the } \\
\text { lower rows, the least. They then } \\
\text { had to justify their rankings to the } \\
\text { rest of their group (of three or } \\
\text { four). Students were encouraged to } \\
\text { debate and challenge one another, } \\
\text { revisiting and rearranging their } \\
\text { cards as they saw fit. }\end{array}$ & $\begin{array}{l}\text { Cards cut out and } \\
\text { used to create a } \\
\text { 'diamond nine', } \\
\text { see Worksheet } 2 \\
\text { (Figure 2). }\end{array}$ & $\begin{array}{l}\text { To ensure, through the } \\
\text { style of activity, that } \\
\text { students appreciate } \\
\text { that there is no fixed or } \\
\text { definite answer to what } \\
\text { the purpose of historical } \\
\text { study actually is. } \\
\text { To allow students } \\
\text { to form their own } \\
\text { perspectives on } \\
\text { the purposes of } \\
\text { historical study. }\end{array}$ \\
\hline
\end{tabular}




\section{Harari's 'History of lawns'}

Read: Harari, Y.N. (2016) Homo Deus: A brief history of tomorrow. London: Vintage, 6774.

Please answer the following questions:

1) According to Harari, the purpose of studying history is not to attempt to predict the future, nor to attempt to repeat successes of the past or to avoid failures from it. What reasons does he give for this argument?

2) Read the final paragraph on page 68. What point do you think Harari is making in that paragraph?

3) Overall, what does Harari think is the purpose of studying history? Explain as fully as you can.

Figure 1: Worksheet 1

Cut out the following cards to use in the diamond nine activity.

\begin{tabular}{|l|l|l|}
\hline $\begin{array}{l}\text { History helps } \\
\text { us understand } \\
\text { other people } \\
\text { and other } \\
\text { societies }\end{array}$ & $\begin{array}{l}\text { History helps us } \\
\text { understand our } \\
\text { society }\end{array}$ & $\begin{array}{l}\text { History } \\
\text { allows us to } \\
\text { orientate } \\
\text { ourselves in } \\
\text { time }\end{array}$ \\
\hline $\begin{array}{l}\text { History can be } \\
\text { beautiful, } \\
\text { moving and } \\
\text { inspiring }\end{array}$ & $\begin{array}{l}\text { History } \\
\text { contributes to } \\
\text { moral } \\
\text { understanding }\end{array}$ & $\begin{array}{l}\text { History } \\
\text { provides } \\
\text { identity }\end{array}$ \\
\hline $\begin{array}{l}\text { History is } \\
\text { essential for } \\
\text { good } \\
\text { citizenship }\end{array}$ & $\begin{array}{l}\text { History helps } \\
\text { us develop } \\
\text { disciplinary } \\
\text { skills }\end{array}$ & $\begin{array}{l}\text { History is } \\
\text { useful in the } \\
\text { world of } \\
\text { work }\end{array}$ \\
\hline
\end{tabular}

Figure 2: Worksheet 2 
rather than questioning the things that exist in our time. Harari (2016: 74) concludes his history of lawns with:

Having read this short history of the lawn, when you come to plan your dream house you might think twice about having a lawn in the front yard. You are of course still free to do so. But you are also free to shake off the cultural cargo bequeathed to you ... This is the best reason to learn history: not in order to predict the future, but to free yourself of the past and imagine alternative destinies. Of course, this is not total freedom - we cannot avoid being shaped by the past. But some freedom is better than none.

While the use of Harari's (2016) work was considered to be beneficial, the whole set of material presented aimed not to promote a particular view of the purpose of studying history, but to expose students to a range of different ideas. To this end, Stearns's excellent summary of eight principal arguments, 'Why study history?' (1998), was used, with adaptations for the purposes of the intervention - mainly by rendering the arguments more distinct in preparation for the sorting activity within the lesson (see Figure 2), via changes to the headings, and by adding a 'historical consciousness' subsection (below), heavily relying on Cooper and Chapman (2009: 2) and Lee (2004):

\section{History allows us to orientate ourselves in time}

Whether people realize it or not, everything in their lives is shaped both by the legacies of the past and by the 'history stories' we all tell ourselves. So, there is no alternative to thinking historically. By thinking about our lives, as we all do, we have to consider history. Therefore, the choice is between trying to do this well - by applying historical knowledge, understanding and thinking to the problems that we all face as historical beings - or by setting out to do it badly, without historical education and in a way that only views our world and our lives through the lens of the present. Past, present and future are a continuum. By being conscious of our place in a continuum of time, and aware of the patterns that have led us here, we can better assess our present situation and consider possible futures. This orientation allows us to cope with life in our own time.

Sorting activities can be a very effective way of eliciting students' thoughts about ideas that they do not usually talk about (Barton, 2015: 184-5). The task (see Table 5) allowed students to debate with one another and to arrive at divergent conclusions, so as not to direct their thinking about what they perceive to be the 'correct' conclusion (that is, to reduce participant bias).

Having completed the tasks shown in Table 5, students were then asked the same question as in Stage 1. As during Stage 1, students could not see the responses of others until after they had submitted their own.

\section{Stage 2: Anecdotal observations}

Some anecdotal observations may highlight students' reactions and responses during the stimulus lesson as a backdrop to the analysis of the data.

The students' reactions to the Harari (2016) stimulus when reading and discussing it were both positive and surprising. Pleasure gained from comprehending a new and challenging idea seemed to be visible on the students' faces, and it was discernible in exclamations such as 'That's blown my mind!', and, in turn, is corroborated in their comments. 
One student had a particularly interesting reaction to Harari's work:

Student: It [Harari's extract] is freaking me out.

Teacher: In what way?

Student: If I've never considered lawns before, what else is there in the present that I just accept without question?

Teacher: Isn't that Harari's point, though?

Student: Yes, I get it, but I still don't like it.

The revelation that we often accept the present (and, by extension, the future) without question or consideration had actually felt threatening to at least this one student. Despite this, though, she had understood Harari's argument.

Others instead reveal tentative changes of their historical consciousness (in terms of Rüsen's (2006) patterns of sense-making). For example, in discussion with a group of students, we unintentionally wandered into a conversation about different types of historical consciousness, as defined by Rüsen (2006). Furthermore, it was clear from the discussion that these students were thinking with history, rather than solely thinking about history. The following is a paraphrase of that discussion, following the reading of the Harari extract:

Teacher: So is Harari saying that we should not have lawns?

Student 1: No, that's not what he's saying. [Other students agree with Student 1]

Student 2: I don't think I want a lawn any more.

Teacher: Why not?

Student 2: Well, I don't like what they represent - displays of wealth and status.

Teacher: So your understanding of the past has made you critical of something in the present and might impact your future choices? You want to break with the past? We call that critical historical consciousness.

Student 1: Well, I still want a lawn.

Teacher: Why, do you want a status symbol outside of your home?

Student 1: No, I understand the history of lawns, but the meaning that we associate with them today is not the same as in the past. We can just accept that they look nice to us.

Teacher: So you are conscious of the history, but choose not to let that influence your response. Why else might someone who knows the history of lawns still want one?

Student 3: They might want one in order to show status - to continue the history.

Teacher: True, they might be aware of the history and choose to continue or to honour that history. We might call that traditional historical consciousness.

Teacher: So, how has your understanding of the history of lawns affected you?

Student 1: It gets you thinking about your options for the future more.

\section{Stage 2: Data and discussion}

In spite of there being no difference in task instruction, the number of different ideas about the purpose of studying history in the posts increased notably between Stages 
1 and 2 in the average number of different purposes addressed within the students' responses (from 2.6 to 3.0 per response) (Table 6).

This could suggest that students were considering a greater range of ideas due to the stimuli presented during the lesson. However, students could have simply been 'parroting' or listing different ideas. Of more interest and significance is the nature/ content of the students' responses, rather than the number of different ideas contained within them. Table 7 compares the results from Stage 1 to those of Stage 2.

While the incidence of some of the ideas remained fairly similar from Stage 1 to Stage 2 (FA, DK, EC, CC), there are some notable changes within the data.

First, there is a notable decrease in the number of students identifying knowledge of the past (KP) as a purpose of historical study. It is important to highlight that in the applied definition of that code, this refers to 'knowledge of the past (without further explanation)' (Chapman et al., 2018: 8, my emphasis). This indicates that, due to the stimuli and discussions during the intervention lesson, in their Stage 2 responses, students were more able to fully explain and articulate their ideas.

There is also an evident change in relation to identity. While no students made reference to identity in their Stage 1 responses, 19.5 per cent of students mentioned some form of personal identity (PI) formation in their Stage 2 responses, as well as 7.3 per cent mentioning national identity $(\mathrm{NI})$ and 7.3 per cent mentioning group identity (GI). This change is somewhat surprising, as the issue of identity had not featured strongly in the intervention lesson, appearing as one of the reasons for studying history in the Stearns (1998) material, but not in the Harari (2016: 67-74) extract.

Yet students' comments about identity tended to be brief and underdeveloped. Furthermore, their references almost exclusively highlighted the potential for history to build the identities of others, rather than of themselves. For example, one student wrote, 'People can feel a certain pride in learning about the history of their country or religion', which is notably different to saying, 'I feel a certain pride'. Another said, 'history can help fuel an identity', which again is significantly different to, 'history fuels my identity'. Only one student stated that history 'gives me a sense of identity' (my emphasis added to all quotations in this paragraph).

As such, it is hard to be certain about the impact of the intervention lesson in relation to consideration of identity. I suspect that students have been introduced to a new idea about the purpose of history that they had not previously considered, so

Table 6: The number of different ideas regarding the purpose of studying history within the students' responses

\begin{tabular}{|c|c|c|c|c|c|}
\hline \multirow{2}{*}{$\begin{array}{l}\text { Number of } \\
\text { different ideas } \\
\text { in response }\end{array}$} & \multicolumn{2}{|l|}{ Stage 1} & \multicolumn{2}{|l|}{ Stage 2} & \multirow{2}{*}{$\begin{array}{l}\text { Change Stage } \\
2 \text { to Stage } 1\end{array}$} \\
\hline & $\begin{array}{l}\text { Number } \\
\text { of students }\end{array}$ & $\begin{array}{l}\text { Percentage } \\
\mathrm{N}=41\end{array}$ & $\begin{array}{l}\text { Number } \\
\text { of students }\end{array}$ & $\begin{array}{l}\text { Percentage } \\
\mathrm{N}=41\end{array}$ & \\
\hline 1 & 4 & 9.8 & 5 & 12.2 & 2.4 \\
\hline 2 & 16 & 39.0 & 8 & 19.5 & -19.5 \\
\hline 3 & 17 & 41.5 & 15 & 36.6 & -4.9 \\
\hline 4 & 3 & 7.3 & 9 & 22.0 & 14.7 \\
\hline 5 & 0 & 0.0 & 2 & 4.9 & 4.9 \\
\hline 6 & 1 & 2.4 & 2 & 4.9 & 2.5 \\
\hline \multicolumn{2}{|c|}{ Total number of ideas given } & 105 & & 124 & +19 \\
\hline \multicolumn{2}{|c|}{$\begin{array}{l}\text { Average number of } \\
\text { ideas/student }\end{array}$} & 2.6 & & 3.0 & +0.4 \\
\hline
\end{tabular}




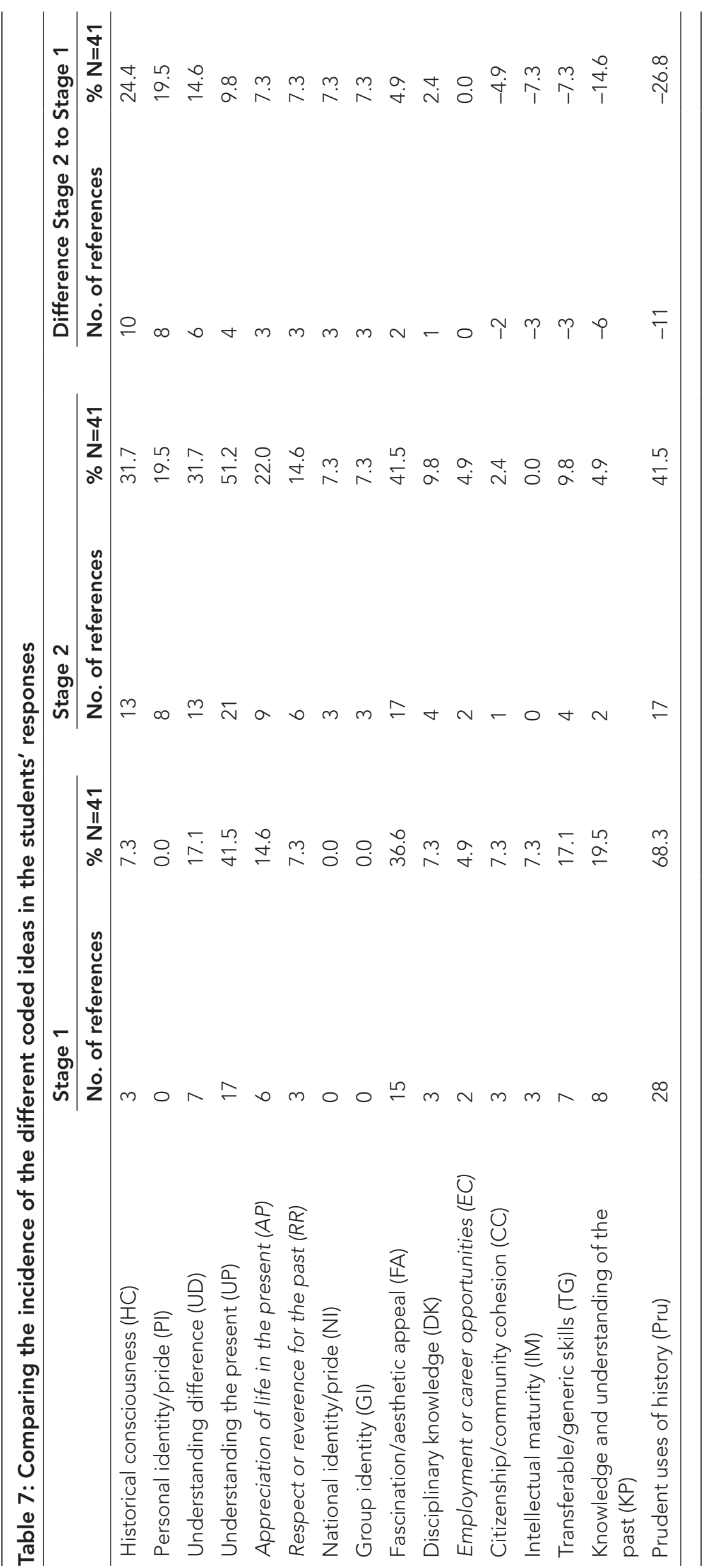


they felt that they wanted to include it (or felt that they should, due to participant bias), but they have not fully grasped the issue. The issue of identity is, therefore, certainly one that should be further explored and discussed with the students in the future.

By far the most significant change in responses between Stage 1 and Stage 2 is the decline in the incidences of references to prudential uses of history (Pru, a decrease of 26.8 per cent), and the increase in consideration of historical consciousness ( $\mathrm{HC}$, an increase of 24.4 per cent). These are discussed together, as what can be seen in the responses is a reduction in comments of the type, 'we have to learn from the mistakes of the past', and a move towards explanations that show understanding of the temporal dimension that spans past, present and future. It is important to emphasize that none of the students used the term 'historical consciousness', but 31.7 per cent presented an understanding of that temporal dimension, or, as Chapman et al. (2018: 8) define it, they 'understand living in time'.

In the extracts below, the influence of Harari's (2016) ideas on their thinking can clearly be identified. In what could be considered the most sophisticated response, one student fully explained her thinking:

Our reality is built up of a sequence of historical events - the past - which influences how we perceive the world and guides our expectations of the future. Only when the fact that each person - in the past and alive now has acted and continues to act in the context of their own historical reality is recognised, can we truly progress in our attempt to answer the question of why our species acts the way that we do. In this way, history not only provides an opportunity to understand ourselves and each other but is in fact a necessity for anyone trying to gain this understanding. How can one begin to have an understanding of the present without first having the knowledge of what has shaped it? History allows us to recognise that what we have been born into - the society, political system, the culture - is not the 'natural' or inherently right way to live because there is no 'natural' way to live - only what was done first, what was done by the most or what was done by those with the most power and influence ... Therefore, I believe that the purpose of history is to appreciate the presence of a possibility for the future that does not necessarily lie within the confines of the path that our historical context has projected for us.

A similar idea was expressed by another student:

We are born into a society which already has predetermined values and normalities that we will conform to simply because we are unaware of possible alternatives. Only by studying history can you unlock the origins of our modern standards, which can date back thousands and thousands of years. Perhaps upon discovery of said origins one might decide that they no longer agree or want to associate with this societal constant, subsequently creating innovation and change.

While these responses, and others like them, indicate that students can grasp some complex ideas about the purpose of historical study, it is also necessary to balance this somewhat by stating that there were some misconceptions that had clearly emerged due to the choice of stimulus material. One student incorrectly understood Harari's (2016) argument to mean that the future is inevitable, so there is no point in trying to anticipate what it might hold. What Harari (2016: 68) actually argues is that people tend 
to see the present as an inevitable outcome of the past, meaning they neither question the present nor, by extension, consider possible futures. This is a significant difference in ideas (with the former undermining the importance of historical study, and the latter emphasizing its value).

Another student wrote:

I believe that history is a source of random events that happened due to the circumstances of that time period and despite knowing history we can never try predicting it or improve our own as we are faced with different issues.

Harari (2016) does make a point about the unpredictability of events and the challenges of anticipating the future, but this particular student has extended this further to mean that we should not try to improve the future as events are 'random'. This is a concerning misconception, both in terms of the importance of studying history, and also in respect of an individual's sense of agency within the world.

While responses such as this were a small minority, it is important to consider what misconceptions may be established or reinforced in the students' minds.

\section{Conclusion}

Contrary to the findings of earlier research, conducted with younger students, it was apparent even from Stage 1 responses that students did see value in the study of history. What was also clear was that students valued the subject for itself: its fascination, its role in understanding the present and understanding others, and its value in providing us with lessons, both positive and negative. As already stated, it is possible that this difference may be explained by the fact that the student participants in this study were both older and had chosen to study history at A level and, to do so, they must have seen some value in it. It would be interesting to conduct a study using the same methodology assessing the views of those students who did not choose to continue a history education past the age 16 years old.

While the findings of this study cannot evidence a lasting change in students' understanding, they do indicate that an impact can be made on the breadth and complexity of students' understanding about the purpose of studying history within a fairly short space of time. After just 1.5 hours of studying two short stimulus materials, students were beginning to consider ideas that they had not explored before (about identity and historical consciousness), they were questioning some of their own ideas (about prudential uses of history), and they were better able to articulate their ideas (explaining the value of knowledge of the past). This latter point is very important. Our students are ambassadors for our subject. Their perceptions of its value will be shared with friends and family. If they cannot articulate why history is valuable, then this has wider implications for the subject.

Yet, this said, 1.5 hours was not enough. Unfamiliar ideas, such as those surrounding identity, were not explored enough. Some students were questioning their views about prudential uses of history, but seemed unclear as to why. Other students had misconceptions surrounding the more complex concepts. As one student commented within the lesson, 'I cannot rank the ideas [in the diamond nine] as I haven't got my head around them all.' It was a valid and important point. For some students, there was a sense that the intervention lesson had caused them to deconstruct some of their existing ideas, without allowing them the thinking time to fully reconstruct new ideas. In my future teaching, it will be necessary to revisit some of the ideas explored 
within the intervention lesson. Perhaps a further lesson that allows students to delve more deeply into some of the key ideas and debates will be beneficial.

Although this paper presents only a small-scale study, its findings may have wider implications. England is one of only a few European countries where students can choose to stop studying history before the age of 16 (many drop it at the age of 13 or 14) (Historical Association, 2014). In 2017, for example, 45.1 per cent of English students studied history at GCSE level (usually 14-16 years old) (Carroll and Gill, 2018). In the same year, only 16 per cent of those students progressed from GCSE to A level history (Gill, 2019). As professionals who work in history education, it can be assumed that we would like to see this figure increasing. Yet for this to happen, students need to be convinced of the value of the subject. This study strongly suggests that those students who have been convinced of its value (and so chose to study it at A level) recognize the intrinsic merits of the subject. It would appear that they did not choose to study history because it is the route to a particular career or because they are developing transferable skills. They seem to have chosen to study it because they recognize the importance of history in explaining the present, in explaining others, in helping us to consider or better determine possible futures, or simply because it fascinates them. Perhaps the history teaching community needs to focus less on 'selling' history on its extrinsic merits. Instead, if earlier in their history education, more students were exposed to the ideas about the intrinsic value of the subject, then maybe we would witness more students choosing to continue their historical studies further.

\section{Notes on the contributor}

Dan Nuttall is a practising history teacher with 15 years' experience, predominantly working in state schools in England. As well as authoring history textbooks and educational resources, he engages with classroom-based research. His particular interests concern scale-switching, historical consciousness, and debates surrounding the purposes and aims of history education. The research considered here was conducted for his master's studies with UCL Institute of Education.

\section{References}

Anderson, B. (2006) Imagined Communities: Reflections on the origin and spread of nationalism. London: Verso.

Barton, K.C. (2015) 'Elicitation techniques: Getting people to talk about ideas they don't usually talk about'. Theory \& Research in Social Education, 43 (2), 179-205. https://doi.org/10.1080/00933104 .2015.1034392.

Barton, K.C. and Levstik, L.S. (2004) Teaching History for the Common Good. London: Routledge.

Blow, F. (2011) '"Everything flows and nothing stays": How students make sense of the historical concepts of change, continuity and development'. Teaching History, 145, 47-55.

Blow, F., Rogers, R., Shemilt, D. and Smith, C. (2015) 'Only connect: How students form connections within and between historical narratives'. In Chapman, A. and Wilschut, A. (eds), Joinedup History: New directions in history education research. Charlotte, NC: Information Age Publishing, 279-316.

Burns, J. (2013) 'Draft history curriculum "list-like and too narrow"'. BBC News, 11 April. www.bbc.co.uk/news/education-22072703 (accessed 5 June 2020).

Cannadine, D., Keating, J. and Sheldon, N. (2011) The Right Kind of History: Teaching the past in twentieth-century England. Basingstoke: Palgrave Macmillan.

Carroll, M. and Gill, T. (2018) Uptake of GCSE Subjects 2017 (Statistics Report Series No. 120). Cambridge: Cambridge Assessment.

Chapman, A. (2020) 'Learning lessons from the Holocaust: A critical exploration'. In Foster, S. Pearce, A. and Pettigrew, A. (eds), Holocaust Education: Contemporary challenges and controversies. London: UCL Press, 50-73. 
Chapman, A., Burn, K. and Kitson, A. (2018) 'What is school history for? British student-teachers' perspectives'. ARBOR Ciencia, Pensamiento y Cultura, 194 (788). https://doi.org/10.3989/ arbor.2018.788n2003.

Collins, M. and Stearns, P. (2020) Why Study History? London: London Publishing Partnership.

Cooper, H. and Chapman, A. (2009) Constructing History 11-19. Los Angeles: Sage.

DfE (Department for Education) (2008) Key Stage 3 National Curriculum in England. London: DfE.

DfE (Department for Education) (2013) 'National Curriculum in England: History programmes of study', 11 September. www.gov.uk/government/publications/national-curriculum-in-englandhistory-programmes-of-study/national-curriculum-in-england-history-programmes-of-study (accessed 1 January 2020).

Fordham, M. (2016) 'Knowledge and language: Being historical with substantive concepts'. In Counsell, C., Burn, K. and Chapman, A. (eds), Masterclass in History Education: Transforming teaching and learning. London: Bloomsbury, 43-58.

Fordham, M. (2020) 'Ethics and history education'. Clio et cetera, 20 June 2020. https://clioetcetera. com/2020/06/20/ethics-and-history-education/ (accessed 26 October 2020).

Gill, T. (2019) Progression from GCSE to A level, 2017 (Statistics Report Series No. 124). Cambridge: Cambridge Assessment.

Guldi, J. and Armitage, D. (2014) The History Manifesto. Cambridge: Cambridge University Press.

Harari, Y.N. (2016) Homo Deus: A brief history of tomorrow. London: Vintage.

Hargreaves, D.H. (1984) Improving Secondary Schools: Report of the Committee on the Curriculum and Organisation of Secondary Schools. London: Inner London Education Authority.

Haydn, T. and Harris, R. (2010) 'Pupil perspectives on the purposes and benefits of studying history in high school: A view from the UK'. Journal of Curriculum Studies, 42 (2), 241-61. https://doi. org/10.1080/00220270903403189.

Hirsch, E.D. (1988) Cultural Literacy: What every American needs to know. New York: Random House.

Historical Association (2014) 'You spoke. We listened. Our response to the History Consultation 2013', 16 April. www.history.org.uk/ha-news/news/1779/you-spoke-we-listened-our-response-tothe-histor (accessed 15 January 2020).

Lee, P. (2004) '"Walking backwards into tomorrow": Historical consciousness and understanding history'. The International Journal of Historical Learning, Teaching and Research, 4 (1), 34-67. https://doi.org/10.18546/HERJ.10.2.07.

Lee, P. and Shemilt, D. (2003) 'A scaffold, not a cage: Progression and progression models in history'. Teaching History, 113, 13-23.

Lee, P. and Shemilt, D. (2004) '"I just wish we could go back in the past and find out what really happened": Progression in understanding about historical accounts'. Teaching History, 117, 25-31.

Lee, P. and Shemilt, D. (2009) 'Is any explanation better than none?: Over-determined narratives, senseless agencies and one-way streets in students' learning about cause and consequence in history'. Teaching History, 137, 42-9.

Mansell, W. (2013) 'Michael Gove redrafts new history curriculum after outcry'. The Guardian, 21 June 2013. www.theguardian.com/education/2013/jun/21/michael-gove-history-curriculum (accessed 5 June 2020).

McDaniel, T.R. (2009) 'Review of Cultural Literacy: What every American needs to know'. The Clearing House: A journal of educational strategies, issues and ideas, 82 (4), 201-2. https://doi.org/10.3200/TCHS.82.4.201-202.

Nuttall, D. (2013) 'Possible futures: Using frameworks of knowledge to help Year 9 connect past, present and future'. Teaching History, 151, 33-44.

Ofqual (Office of Qualifications and Examinations Regulation) (2014) GCE Subject Level Conditions and Requirements for History. www.gov.uk/government/publications/gce-subject-levelconditions-and-requirements-for-history (accessed 2 January 2020).

Rüsen, J. (2006) 'Historical consciousness: Narrative structure, moral function and ontogenetic development'. In Seixas, P. (ed.), Theorizing Historical Consciousness. Toronto: University of Toronto Press, 63-85.

Santayana, G. (1905) The Life of Reason: Reason in common sense. London: Archibald Constable \& Co.

Schools Council (1968) Enquiry: London: Schools Council. London: Schools Council.

Seixas, P. (2017) 'A model of historical thinking'. Educational Philosophy and Theory, 49 (6), 593-605. https://doi.org/10.1080/00131857.2015.1101363.

Seixas, P. and Morton, T. (2013) The Big Six Historical Thinking Concepts. Toronto: Nelson Education. 
Shemilt, D. (2000) 'The caliph's coin: The currency of narrative frameworks'. In Seixas, P., Stearns, P. and Wineburg, S. (eds), Knowing, Teaching, and Learning History: National and international perspectives. New York: New York University Press, 119-61.

Stearns, P. (1998) 'Why study history?' Washington: American Historical Association. www.historians. org/about-aha-and-membership/aha-history-and-archives/historical-archives/why-studyhistory-(1998) (accessed 2 January 2020).

Tuchman, B. (1978) A Distant Mirror: The calamitous 14th Century. London: Macmillan.

Van Straaten, D., Wilschut, A. and Ootsdam, R. (2016) 'Making history relevant to students by connecting past, present and future: A framework for research'. Journal of Curriculum Studies, 48 (4), 479-502. https://doi.org/10.1080/00220272.2015.1089938.

Van Straaten, D., Wilschut, A. and Ootsdam, R. (2017) 'Measuring students' appraisals of the relevance of history: The construction and validation of the Relevance of History Measurement Scale (RHMS)'. Studies in Educational Evaluation, 101-11. https://doi.org/10.1016/j. stueduc.2017.12.002.

Wertsch, J. (2002) The Voices of Collective Remembering. Cambridge: Cambridge University Press.

Wineburg, S. (2018) Why Learn History (When It's Already On Your Phone). Chicago: Chicago University Press. 